\title{
EPIDURAL ABSCESS AND SIGMOID SINUS THROMBOSIS AS INTRACRANIAL COMPLICATIONS OF THE MIDDLE EAR CHOLESTEATOMA
}

Dalibor Vranjes ${ }^{1,2}$, Aleksandar Gajic ${ }^{3}$, Svjetlana Jefic ${ }^{4}$, Slobodan Spremo ${ }^{1,2}$, Dmitar Travar ${ }^{1,2}$, Sanja Spiric ${ }^{1,2}$, Mirjana Gnjatic ${ }^{1,2}$, Predrag Spiric ${ }^{1,2}$

${ }^{1}$ University of Banjaluka, Faculty of Medicine, Banjaluka, Republic of Srpska, Bosnia and Herzegovina

${ }^{2}$ Ear, Throat and Nose Department, The University Clinical Centre of the Republic of Srpska, Banjaluka, Republic of Srpska, Bosnia and Herzegovina

${ }^{3}$ Centre for Hyperbaric Medicine and Chronic Wounds Treatment at Institute for Rehabilitation and Physical Medicine "Dr Miroslav Zotović", Banjaluka, Republic of Srpska, Bosnia and Herzegovina

${ }^{4}$ Department of Radiology, The University Clinical Centre of the Republic of Srpska, Banjaluka, Republic of Srpska, Bosnia and Herzegovina

\section{EPIDURALNI APSCES I TROMBOZA SIGMOIDNOG SINUSA KAO INTRAKRANIJALNE KOMPLIKACIJE HOLESTEATOMA SREDNJEG UHA}

\author{
Dalibor Vranješ $\check{x}^{1,2}$, Aleksandar Gajić ${ }^{3}$, Svjetlana Jefić4, Slobodan Spremo ${ }^{1,2}$, Dmitar Travar ${ }^{1,2}$, Sanja Špirić1,2, Mirjana Gnjatić1,2, Predrag Špirić1,2 \\ ${ }^{1}$ Univerzitet u Banjaluci, Medicinski fakultet, Banjaluka, Republika Srpska, Bosna i Hercegovina \\ ${ }^{2}$ Klinika za bolesti uha, grla i nosa, Univerzitetski klinički centar Republike Srpske, Banjaluka, Republika Srpska, Bosna i Hercegovina \\ ${ }^{3}$ Centar za hiperbaričnu medicinu i tretman hroničnih rana Zavoda za fizikalnu medicinu i rehabilitaciju "Dr Miroslav Zotović", \\ Banjaluka, Republika Srpska, Bosna i Hercegovina \\ ${ }^{4}$ Zavod za kliničku radiologiju, Univerzitetski klinički centar Republike Srpske, Banjaluka, Republika Srpska, Bosna i Hercegovina
}

\section{ABSTRACT}

The otogenic intracranial complications are rare manifestations in modern era of antibiotics. An early antibiotic therapy often covers typical clinical signs and symptoms for each complication. A sigmoid sinus thrombosis is often associated with other intracranial complications, as in this case, an epidural abscess. We are presenting a case of 12-year-old girl with the sigmoid sinus thrombosis and epidural abscess as complications of chronic infection to the middle ear with cholesteatoma. In the active phase of chronic inflammation of the middle ear she was treated with the antibiotic therapy that covered early symptoms of intracranial complication development. A humid attic perforation of the tympanic membrane with protrusion of choleastoma and evident signs of bony wall destruction to the external auditory canal was noticed by performing routine otomicroscopy and otoendoscopic examination. Assuming intracranial complication, magnetic resonance imaging (MRI) of the endocranium was undertaken. The MRI showed inflammatory changes of both middle ears with intracranial complications: the right sigmoid sinus thrombosis and epidural abscess of the same side. During the surgery we have noticed an extensive middle ear cholesteatoma with significant destruction of the bony tissue and purulent collection between sigmoid sinus changed with granulation and respective dural segment of the posterior cranial cavity.

Timely diagnosis, multidisciplinary approach with an adequate choice of the antibiotic therapy and surgical technique have a crucial prognostic significance.

Key words: Sigmoid sinus thrombosis, epidural abscess, middle ear inflammation, cholesteatoma

\section{SAŽETAK}

Otogene intrakranijalne komplikacije u današnjoj eri antibiotika su rijetka pojava. Rana antibiotska terapija često maskira tipične kliničke znakove i simptome za svaku komplikaciju. Tromboza sigmoidnog sinusa često je udružena $s$ drugim intrakranijalnim komplikacijama, kao što je to u ovom slučaju epiduralni apsces. U radu je prikazan slučaj 12-godišnje pacijentkinjes trombozom sigmoidnog sinusa $i$ epiduralnim apscesom kao komplikacijama hronične upale srednjeg uha s holesteatomom. U aktivnoj fazi hroničnog upalnog procesa srednjeg uha, pacijentkinja je tretirana antibiotskom terapijom koja je maskirala rane simptome razvoja intrakranijalnih komplikacija. Otomikroskopskim i otoendoskopskim pregledom, uočena je vlažna atik perforacija membrane timpani kroz koju je prominirao holesteatom $s$ znakovima destrukcije koštanog zida spoljašnjeg slušnog hodnika. Zbog sumnje na intrakranijalnu komplikaciju, sproveden je NMR pregled endokranijuma, na kojem su očitane zapaljenske promjene oba srednja uha s intrakranijalnim komplikacijama: trombozom desnog sigmodnog sinusa $i$ epiduralnim apscesom $s$ iste strane. Intraoperativno je uočen ekstenzivni holesteatom desnog srednjeg wha s izraženom destrukcijom koštanog tkiva i prisustvom gnojne kolekcije između granulomatozno izmjenjenog sigmoidnog sinusa i pripadajućeg segmenta dure zadnje lobanjske jame.

Na vrijeme postavljena dijagnoza, multidisciplinarni pristup s adekvatnim izborom antibiotske terapije $i$ hirurške tehnike, imaju presudan prognostički značaj.

Ključne riječi: tromboza sigmoidnog sinusa, epiduralni apsces, srednje uho, upala, holesteatom

\section{ABBREVIATIONS}

SST - Sigmoid Sinus Thrombosis; LST - Lateral Sinus thrombosis;

\section{sciendo}

UDK: 616.284-002.56/.58

Ser J Exp Clin Res 2020; 21 (2): 179-183 DOI: 10.2478/SJECR-2018-0044
EA - Epidural Abscess;

COM - Chronic Otitis Media;

MRI - Magnetic Resonance Imaging

Corresponding author: Mr sc. med. Dalibor Vranjes, Ear, Troat and Nose Department, Te University Clinical Centre of the Republic of Srpska, Bosnia and Herzegovina, 12 beba bb, 78000 Banjaluka Telephone: +38751342 666; Fax: +38751342663,
e-mail: dalibor.vranjes@yahoo.com 


\section{INTRODUCTION}

A chronic middle ear inflammation (Chronic Otitis Media - COM) is characterized by insidious and asymptomatic onset, slow and long duration as well as with potentially large, destructive effects, especially when cholesteatoma is present. COM has more aggressive and persistent characteristics in childhood than in adult period of life. The main characteristic of choleasteatoma is a progressive growth with erosion of nearby bone structures due to the pressure effect and activation of the osteoclasts. Cholesteatomas can be classified as either congenital, that occur in $2-4 \%$ of cases or acquired. An annual incidence of acquired cholesteatomas is 3 in 100.000 in childhood and 9.2 in 100.000 in adult population, predominantly in males (1-3).

Intracranial complications due to otogenic infections are present even in the era of modern antibiotics (4). If they are not adequately and timely managed, they can be fatal. Ludman (5) has classified otogenic complications into intracranial (extradural and subdural abscess, sigmoid sinus thrombosis, otitic hydrocephalus, meningitis and cerebral abscess) and intratemporal (facial paralysis, labyrinthitis). Treatment includes antibiotic therapy, neurosurgical procedure when needed and otosurgical management in the temporal bone. COM, cholesteatoma and brain abscess are diagnosed mainly in adults, while COM and epidural abscess $(E A)$ are more common in children (6).

Meningitis is the most common intracranial complication, associated with brain abscess and lateral sinus thrombosis $(L S T)$. Otogenic meningitis is most commonly followed by brain abscess, which aggravates timely diagnostics for each complication. Development of otogenic intracranial complications is significantly reduced with introduction of an antibiotic therapy, improved diagnostic methods and surgical management of COM. An early antibiotic treatment often covers specific clinical signs and symptoms for each complication $(4,7)$.

LST occurs when mastoid infection involves nearby lateral and sigmoid sinuses. Because of that, perisinus EA is common accompanying finding. LST treatment has been a subject of certain controversye. Most of the authors agree that minimal intervention includes intravenous application of antibiotics and mastoidectomy. Beside that, a recanalization of the blood vessel in order to develop collateral circulation, usually normalize pressure of the cerebrospsinal fluid after evacuation of the surrounding infection. EA abscess is an inflammatory process located within the potential space between the skull and lateral surface of the dura. A purulent collection is rare, more commonly a dural granulomatous tissue is in direct contact with suppuration from the temporal bone. EA treatment includes intravenous administration of antibiotics and surgical drainage. Cortical mastoidectomy with sufficient removal of the bone tissue enables direct inspection of dura and posterior cranial cavity. The most certain method of an early diagnostics of EA and sigmoid sinus thrombosis (SST) is magnetic resonance imaging (MRI) (8).
The case report presents a 12-year-old girl with SST and $\mathrm{EA}$ as a complication of the COM with cholesteatoma.

\section{CASE REPORT}

A 12-year-old girl, hospitalized at the Ear, Throat and Nose Department for a the headache, a right otalgia and otorrhea, postauricular pain, fever and vertigo. Previously, she underwent diagnostic evaluation and treatment in local general hospital and at the departments for paediatric and infective diseases. A redness, mild oedema and palpatory pain sensitivity over the right mastoid process was noticed during the clinical examination at the admission at the Ear, Throat and Nose Department.

After microaspiration of the purulent discharge from the right external auditory canal, a humid attic perforation of the tympanic membrane, with protrusion of cholesteatoma, was noticed by performing routine otomicroscopy and otoendoscopic examination (Figure 1). A dry attic perforation of the tympanic membrane was noticed on the left side. Signs of the posterior and upper wall bone destruction to the both external auditory canals were also noticed.

Both orthostatic and dynamostatic tests were positive: instability in walking and standing, staggered, especially during the tandem walk. Pure tone audiometry showed a right moderate, and left mild conductive hearing loss. Laboratory findings: C-reactive protein level was $0.5 \mathrm{mg} /$ $\mathrm{dL}$, white blood cells $8.5 \times 10^{9} / \mathrm{L}$, neutrophill granulocytes $77.3 \%$, procalcitonin $0.05 \mathrm{ng} / \mathrm{mL}$. Findings of EEG, lumbar puncture and examination of the eye fundus were normal. MRI of the endocranium was indicated and performed. MRI showed inflammatory changes of both middle ears with endocranial complications: the right SST and EA of the same side (Figure 2).

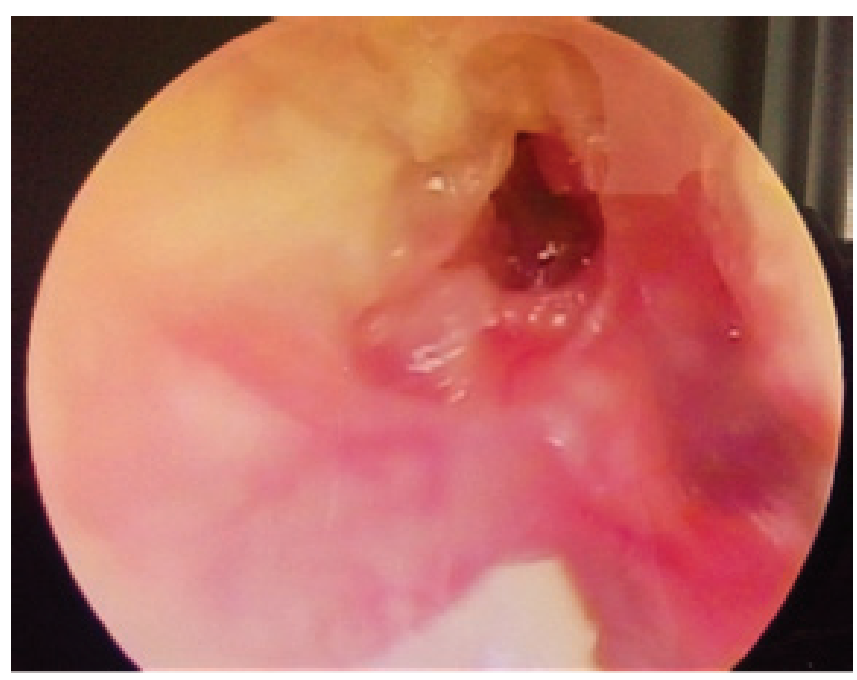

Figure 1. Otoendoscopic image: The humid attic perforation of the tympanic membrane, with protrusion of cholesteatoma. 


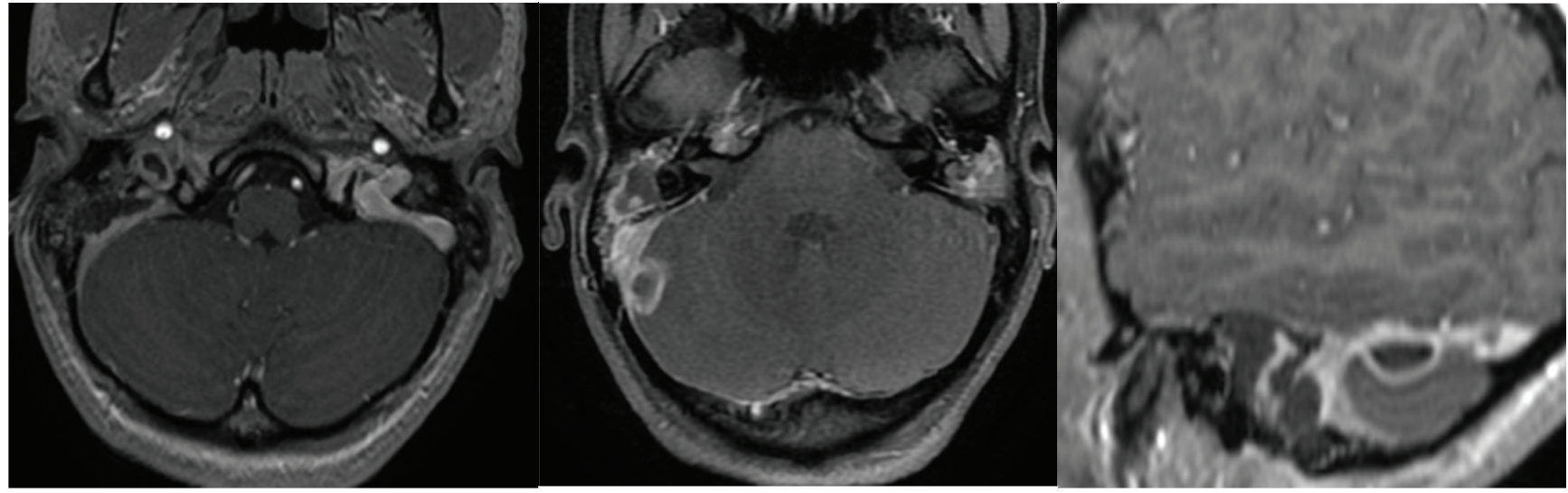

Figure 2. Initial MR images $(\mathrm{T} 1 \mathrm{~W}+\mathrm{C}$, axial and sagittal view): at the convexity of the right cerebellar hemisphere epidural empyema; the right sigmoid sinus is without normal opacification and dilated due to content of thrombus, with an erosion of the anterior wall and in continuity with right mastoid and middle ear that are filled with granulation tissue.

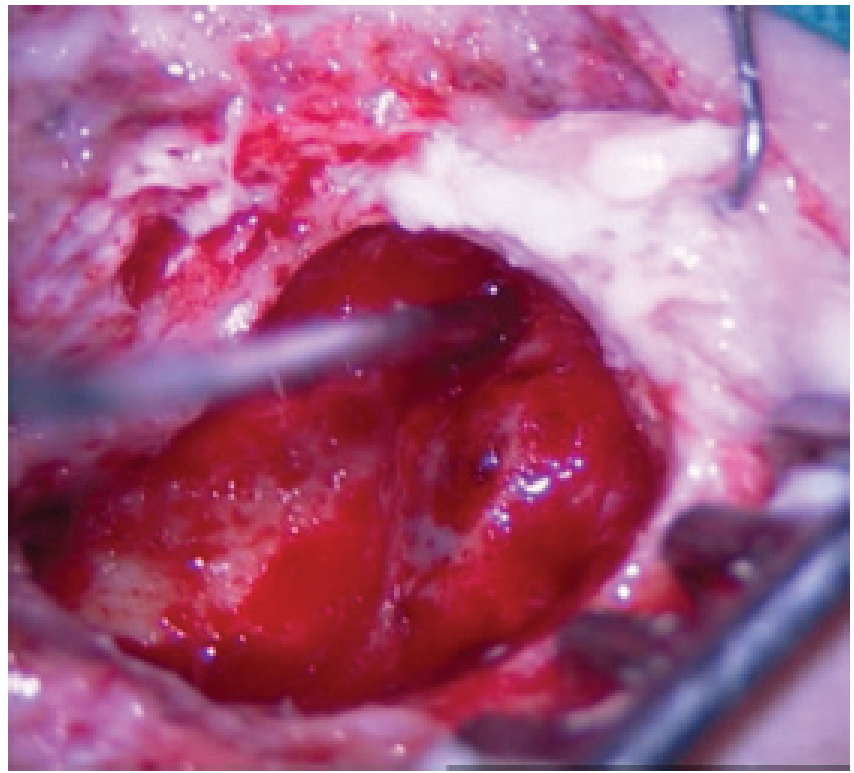

Figure 3. Intraoperative otomicroscopic image: The sigmoid sinus and posterior cranial cavity dura were covered with granulomatous and abscess collection in the epidural space.

A neurosurgeon was consulted and declared that there were no indications for neurosurgical treatment. A triple systemic antibiotic therapy was introduced (third generation cephalosporines, metronidazole and glycopeptide antibiotic), as well as antiedema therapy (osmotic diuretic), analgesics and antipyretic therapy. An otosurgical treatment was indicated under general anaesthesia.

During the surgery we have noticed an extensive cholesteatoma in the area of the mastoid process, which completely filled antrum and aditus ad antrum and destroyed mastoid cells. The bony plate of the sigmoid sinus and belonging segment of the bony wall of the posterior cranial cavity were destroyed. The sigmoid sinus and posterior cranial cavity dura were covered with granulomatous and abscess collection in the epidural space (Figure 3). During the trepanation a huge purulent collection was spontane- ously drainaged from the epidural abscess, followed by liquorrhea which stopped spontaneously. A smear from the abscess was sent for microbiological analysis. After a consultation with a neurosurgeon, a lavage was performed with $3 \%$ hydrogen peroxide solution, isotonic saline solution, povidone iodine solution and antibiotics from aminoglycoside class.

After elevation of the tympanomeatal lobe and removal of the posterior bony wall of the auditory canal, we noticed presence of cholesteatoma in the area of attic, oval fossa and retrotympanon as well as dehiscence of the attic tegmen and bony canal of the tympanal part of the facial nerve. An ossicular chain was disarticulated in the area of incudostapedal joint, while the suprastapedial structures were preserved. The mucosa of the tympanal cavity was hypertrophic, and the Eustachian tube orifice was not occluded. The fragments of the cholesteatoma were sent to the pathohistological analysis (Figure 4). The surgery was finished with open technique of tympanoplasty (tympa-

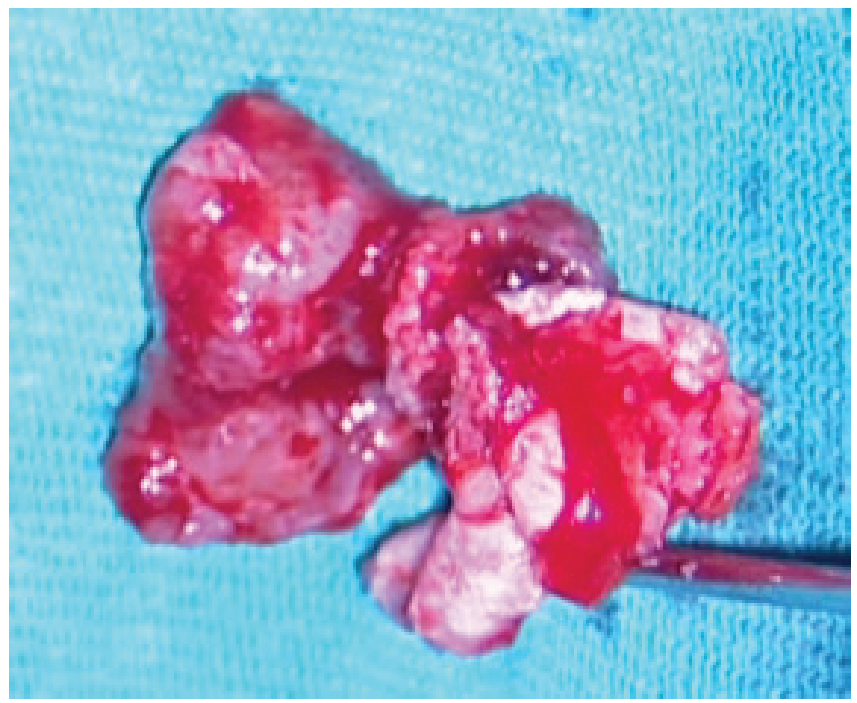

Figure 4. Intraoperative otomicroscopic image: The removed cholesteatoma. 


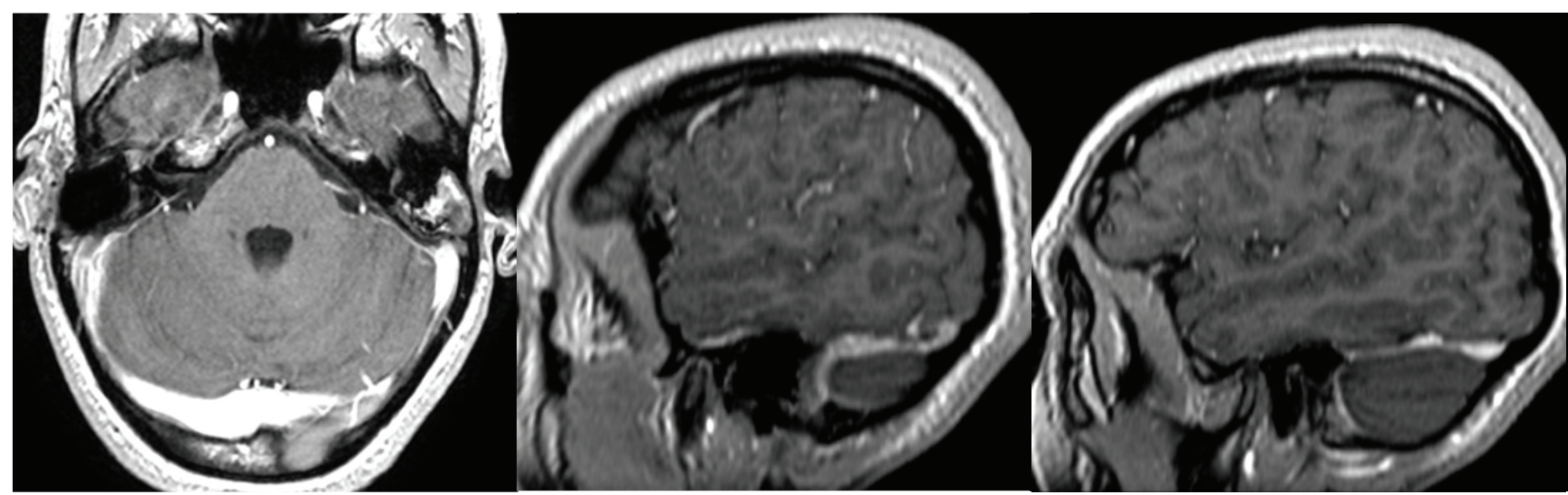

Figure 5. On the control MR exam $(\mathrm{T} 1 \mathrm{~W}+\mathrm{C}$, axial and sagittal view) it is visible a complete resolution of the epidural empyema and partial recanalization of the right sigmoid sinus.

nomastoidectomy). The operative and early postoperative period passed correctly.

The microbiological analysis of the smear taken from the abscess isolated Staphylococcus epidermidis, while the pathohistological analysis showed Cholesteatoma. On the ninth postoperative day a control MRI of the endocranium was performed: the abscess in the posterior cranial cavity was not found, while the sigmoid sinus showed signs of partial recanalization (Figure 5) . The patient was discharged on the tenth postoperative day in good general condition and with good postoperative finding. She came after seven days for a control examination, and a postoperative finding was good, as well as her general condition. Surgery of the left ear was indicated and she was operated after four months.

\section{DISCUSSION}

Most of the intracranial complications are caused by COM and cholesteatoma $(95,8 \%)$. They usually occurred in the third decade of lifetime, predominately with male patients. Intracranial and extracranial complications of COM with paediatric populations are relatively rare in developed countries (9).

LST as a complication of otogenic infections can still present a serious threat that requires a prompt management. It is often associated with other intracranial complications, as in this case, with EA. The cholesteatoma manifests more aggressive characteristics in children, with different pattern of spreading and larger incidence of relapses. In patients with otogenic complications the most common intraoperative findings are granulations and cholesteatoma, which was the case with our patient as well. Spreading of the infection through the posterior wall of mastoid process into the posterior segment of the cranial cavity due to the cholesteatoma can cause, a perisinus abscess can be formed. The abscess presses the bone, creating necrosis of the anterior part of the sinus and intima as well as accumulation of fibrin, red blood cells and platelets, which results in thrombus formation on its wall. A throm- bus can penetrate towards bulbus of the inferor vena cava, submucous tissue and even cause an embolism (9-14).

Headache, vomiting and neck stiffness associated with otorrhea and hearing loss are dominating clinical findings of LST. But symptoms may be atypical, hardly recognizable and almost undetectable due to the antibiotic application. The most common symptoms of the patients with LST, as was in this case, are characterized by a permanent and/ or significant temperature rise associated with otorrhea, postauricular edema and otalgia (7).

The case report is also interesting for its silent and clinically undetected development of the EA. In the active phase of the COM, the patient was given an antibiotic therapy that most probably covered early symptoms of the intracranial infection. These facts lead to the conclusion that an otologist always has to bear this in mind and to check if in the active phase of COM an intracranial infection exists. In general, the focal neurological signs are absent. Although EA can be manifested by weak fever, headache and otalgia, a patient is usually asymptomatic and without focal neurological signs $(8,15)$.

The microbiological analysis of the smear taken from the abscess cavity isolated Staphylococcus epidermidis. However, in most of the cases of brain abscess whose etiology is of COM, a gram-negative bacteria were isolated (6).

Radiological examinations are useful in diagnostics, but they have a limited role in identification of tegmen dehiscence, mastoid erosion or meningoencephalocele. In order to increase the probability of correct diagnosis in cases suspected otogenic meningitis and bone defects, it is useful to perform a computed tomography $(C T)$ scan with any possible reconstruction, while MRI can explain intracranial phlogistic processes. EA can often be overseen in CT scan, if a huge volume of pus is not present. It is for this reason that, MRI is considered a method of choice. In the case of LST, a priority is given to the magnetic resonance angiography due to the precise visualization of the vascular flow $(16,17)$.

From the authors experience and the literature review, it is recommended that paediatric patients with otogenic thrombosis of the dural sinus and in the case of increased 
intracranial pressure $(I C P)$ be treated conservatively. A triple antibiotic therapy is administered empirically until the results of microbiological analysis arrive and it should be given when there is a suspicion of possible development of the otogenic complications. A systemic administration of broad-spectrum antibiotics during six weeks is usually sufficient treatment. Treatment of LST is usually with anticoagulants not recommended. A risk of intracerebral haemorrhage, together with possibility of embolism, limits their usage. In the case of EA, if it is indicated, a neurosurgical intervention includes craniotomy and drainage. Otosurgical treatment includes mastoidectomy or tympanomastoidectomy. In the presented case, tympanomastoidectomy successfully eradicated pathological process in the middle ear.

\section{CONCLUSION}

A unique pathophysiology of each intracranial otogenic complication requires different diagnostic and therapeutic approaches. MRI is a method of choice in an early diagnostics of the otogenic intracranial complication. Timely diagnosis, multidisciplinary approach with an adequate choice of the antibiotic therapy and surgical technique have a crucial prognostic significance.

\section{Authors declare that there is no conflict of interest.}

Notice: A study derived from the scientific-research project: "Significance of expression of the inflammatory mediators in middle ear cholesteatoma", received a clearance from the Ministry of science and technology of the Republic of Srpska Government (No. 19/6-020/961-68/15) dated $12^{\text {th }}$ of December 2016.

\section{REFERENCES}

1. Kemppainen HO, Puhakka HJ, Laippala PJ, et al. Epidemiology and aetiology of middle ear cholesteatoma. Acta Otolaryngol 1999;119(5): 568.

2. Frickmann H, Zautner AE. Cholesteatoma - A Potential Consequence of Chronic Middle Ear Inflammation. Otolaryngology: Current Research 2012;5:1-8.

3. Bennett M, Warren F, Jackson GC, Kaylie D. Congenital cholesteatoma: theories, facts, and 53 patients. Otolaryngol Clin North Am 2006;39:1081-94.
4. Wanna GB, Dharamsi LM, Moss JR, Bennett ML, Thompson RC, Haynes DS. Contemporary management of intracranial complications of otitis media. Otol Neurotol 2010;31(1):111-7.

5. Ludman H. Complications of suppurative otitis media. In: Kerr AG, Booth JB, eds. Scott Brown's Otolaryngology. 6th ed. London: Butterworth-Heinemann, 1997:1-29.

6. Migirov L, Duvdevani S, Kronenberg J. Otogenic intracranial complications: a review of 28 cases. Acta Otolaryngol 2005;125(8):819-22.

7. Kaplan DM, Kraus M, Puterman M, Niv A, Leiberman A, Fliss DM. Otogenic lateral sinus thrombosis in children. Int J Pediatr Otorhinolaryngol. 1999;49(3):177-83.

8. Scherer A, Jea A. Pediatric Otogenic Sigmoid Sinus Thrombosis: Case Report and Literature Reappraisal. Global Pediatric Health 2017;4:2333794X17738837. doi:10.1177/2333794X17738837.

9. Penido Nde O, Borin A, Iha LC, Suguri VM, Onishi E, Fukuda Y, et al. Cruz OL. Intracranial complications of otitis media: 15 years of experience in 33 patients. Otolaryngol Head Neck Surg 2005;132(1):37-42.

10. Kangsanarak J, Fooanant S, Ruckphaopunt K, Navacharoen N, Teotrakul S. Extracranial and intracranial complications of suppurative otitis media: report of 102 cases. J Laryngol Otol 1993;107:999-1004.

11. Osma U, Cureoglu S, Hosoglu S. The complications of chronic otitis media: report of 93 cases. Otorhinolaryngology 2000;114:97-100.

12. Erdevički Lj, Krstić Lj, Belić B, Stojanović J, Milojević I. Apsces velikog mozga kao otogena komplikacija. Medicinski časopis 2011;45(3):38-41.

13. Seven H, Ozbal AE, Turgut S. Management of otogenic lateral sinus thrombosis. Am J Otolaryngol. 2004;25(5):329-33.

14. Miura MS, Krumennauer RC, Lubianca Neto JF. Intracranial complications of chronic suppurative otitis media in children. Braz J Otorhinolaryngol 2005;71(5):639-43.

15. Đerić D, Đorđević V, Đurović B. A quiet clinical course in an otogenic brain abscess. Med Pregl 1999;52(1112):505-7.

16. Bruschini L, Fortunato S, Tascini C, et al. Otogenic Meningitis: A Comparison of Diagnostic Performance of Surgery and Radiology. Open Forum Infectious Diseases. 2017;4(2):ofx069. doi:10.1093/ofid/ofx069.

17. Brodner DC, Cutler J, Gianoli GJ, Amedee RG. Epidural abscess masquerading as lateral sinus thrombosis. Skull Base Surg 2000;10(4):201-5 